\title{
Improving Friendly Character through Traditional Game of the Engklek at Thematic Learning
}

\author{
${ }^{1}$ Ika Ari Pratiwi, ${ }^{2}$ Siti Masfuah \\ Elementary School Education Programme of Universitas Muria Kudus, Indonesia \\ $\left\{\right.$ ika.ari@umk.ac.id $\left.{ }^{1}\right\}$
}

\begin{abstract}
This study aims to describe the improvement of friendly character through the application of traditional games during thematic learning in thirdgrade students of Muhammadiyah I Elementary School in Kudus Indonesia. This type of research is a control group pre-test post-test experiment. The results of the research showed that there was a significant increase in the friendly character of the experimental group from the pre-test score of 77 post-test to 83 with a post-test result of 82,97 and the results of the gain test 0,25 low criteria. Based on the results of the data acquisition, it can be seen that through the use of cruciary transient games in learning activities can increase the value of friendly characters that through the use of cruciary transient games on learning activities can increase the value of friendly.
\end{abstract}

Keywords: Friendly Character, Learning Activities, Games

\section{Introduction}

Answering the demands of modern education, especially in elementary schools which are the basic foundation for the nation's future generation must be able to create an atmosphere of learning that is interesting and creative. Learning must be carried out innovatively using strategies, approaches, and activities that are appropriate to the needs of students. Students in school not only need subject matter but in line with this, students need an education that supports growing and developing into a person of character. One of the tools that the government strongly urges to foster national values and personality is the implementation of character education in school learning. The process of developing the values that form the basis of the character requires an ongoing process carried out through the subjects in the curriculum[1].

Character education is carried out to build awareness and insight regarding its place of residence, build and value values in the community, as well as to develop social and cultural systems [1]. The application of character education has never been separated from cultural education that comes from the view of the life of the Indonesian people. Character and cultural education contain several aspects that greatly determine the value and personality of the Indonesian people. However, the development of technology today is beginning to erode Indonesia's national culture. Learning in schools is feared to start eliminating activities related to the preservation of Indonesian culture; for example, all learning facilities no longer pay attention to local wisdom.

The results of preliminary observations at Muhammadiyah 1 Elementary School Kudus in February 2018, found the results that when the following learning experienced problems, 
among others: (a) visible activities of students only individually, (b) two-way communication between teacher and students, (c) students were rarely involved in group activities; and (d) students look saturated learning by recording and listen. The innovation has been innovative using modern tools. But students have not been involved in social activities; the potential of local wisdom has not been raised in the learning material. Student opportunities to play are limited only during breaks, and even then they have to divide their time by eating, going to the library and other activities.

Based on these problems, researchers attempt to provide innovative learning facilities by utilizing traditional children's games that are becoming forgotten. Students are expected to be actively involved in learning by playing with friends using an integrated game of engklek during learning. During the learning activities, the teacher will easily monitor the game carried out by students. Communication between fellow students while playing is expected to foster a sense of familiarity or friendship among students. When the child communicates with his friend, the interaction between two or more students is carried out to develop friendship between them. Playing with objects in their environment is a way for children to learn and solve problems. Thus in this study, the researcher intends to implement friendly characters through traditional children's games[2]. The game that was practiced in this study was the engklek played outdoors.

\section{Literature Review}

\subsection{Friendly Character}

The character is a reflection of the behavior and personality of every human person. The character is the character, character, character or personality of a person formed from the results of internalization of various virtues that are believed and used as a basis for the way of thinking, thinking, and acting consisting of a number of values, norms and morals[1]. The development of one's character occurs in the social and cultural environment in which they live. In the process of developing character, values will never be separated from interaction and social activities with someone or a group. Interaction and socialization with other people greatly determine how behavior as individuals and groups in life, in this process someone learns to secure the value of friendly characters.

Characters have a social value that is always needed by someone in their environment. The ability to be friends greatly influences the role and position of the person with others. Values of a friendly character, namely actions that show pleasure in talking, associating and collaborating with others[1]. Friendly behavior that is: speaking in a polite language, mutual respect, and respect[3]. Explains the behavior of friendly/communicative behavior, among others: students try to work together, establish communication with members of the group, students are able to appreciate the teacher and want to implement the learning prepared by the teacher[4]. Based on the behaviors that have been studied previously, the friendly indicators used in this study students are able to show behavior including (a) working in groups, (b) speaking politely, (c) playing without choosing friends, and (d) paying attention to friends when talking.

\subsection{Traditional Child Games}

The game is a vehicle for children to express themselves. Traditional games are games that are relatively simple but provide extraordinary benefits if you explore the meaning of the 
game in depth. Playing is the most basic children's need to interact in the surrounding world, which is carried out directly and spontaneously with others using surrounding objects with pleasure, voluntary and imaginative[2]. Traditional games as elements of culture that cannot be underestimated, because this game gives a small influence on the psychological development, nature and social life of children in the future[5].

Every region knows traditional games with their names. Traditional games were often played by children to fill their playing days. But now the existence of traditional games has begun to fade for it to be introduced and re-practiced to children so that the cultural values and educational values in the game are not extinct. So there needs to be an effort to preserve traditional games because of the many benefits to child development. Preservation of traditional games is applied to learning activities adapted to the study of teaching materials so that students will interpret lessons using the game. Through playing activities with students, they will have friends that they expect, which they feel are similar and match so that they will be familiar to complement each other.

When children play, that's where friendly character values can be formed in each child by playing children talking to each other, giving input, an instruction to friends. When playing in a group or their team will have the same goal of achieving victory, so the cooperation and cohesiveness between them will be established. The traditional game that was applied in this study was the game engklek. Engklek in the 1970s became a favorite game among children and adolescents, called engklek because of how to play using one leg[6]. Game engklek is called "somdah" which is a game that uses rectangular image media drawn on the floor or on the ground[7].

How to play engklek by jumping with one foot in each plot that was previously drawn on the ground. When playing, every child must use "gacuk" or "kereweng" from tile tiles or floor tiles were thrown into one of the plots. There is no trampling on the plots that the player must step on. So the players must jump to the next plot with one foot around the existing plots. This game is fun for students because it is done outdoors so that students are free to move. According to research Soute, Markopoulos, and Magielse explained that the essential aspects of outdoor play like spontaneous social interaction, physical movement, and rich face-to-face communication[8].

The benefits of playing engklek are: (a) jumping up and down physical abilities to be stronger, (b) honing socialization skills and teaching togetherness, (c) developing children's logical intelligence, (d) practicing children's creativity, and (e) training to obey rules agreed upon, and (f) training children's motor skills by throwing "gacuk". Badu explained the advantages of traditional games for children, namely: (a) economically more economical and easy to make, (b) in terms of education to train children's creativity, (c) practice sportsmanship, cooperation, tenacity, perseverance, discipline, honesty and confidence, and (d) preservation and inheritance of local culture[9]. The game in this research can be seen in Figure 1. 


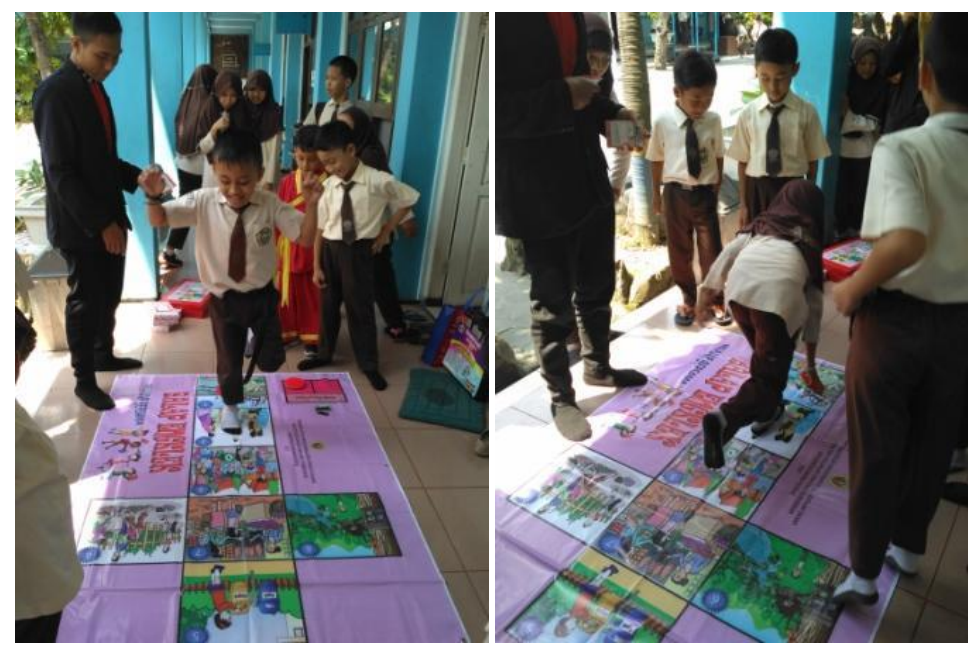

Figure 1. Students do Traditional Games Of Engklek

This research is in line with the results of research by Andriani that traditional games can shape the character for children[2]. Apriani explained that the results of the application of traditional games on the crucian could improve children's motor skills[10]. The results of the application of traditional engklek games can improve children's motor skills and build children's character through these traditional children's games [11].

\section{Method}

Research to improve friendly character through the game crunch using the type of experimental research control group pre-test post-test. The object of research in Muhammadiyah 1 elementary school, class $3 \mathrm{~A}$ as the experimental group and $3 \mathrm{~B}$ as the control group. This research variable is the traditional game engklek as the independent variable and is often friendly as the dependent variable. The instrument to measure the value of characters when doing the crunch game in this study is observation sheets, interview sheets, and quizzes. Data analysis consisted of 1) two variance similarity test, 2) group and experimental homogeneity test and control group, 3) normality test, and 4) research hypothesis test with t-test difference between two averages and 5) Gain test [12].

\section{Result and Discussion}

The presentation of the data from the experimental study of the control group pre-test posttest in Muhammadiyah 1 elementary school about the improvement of friendly behavior through traditional games of engklek is as follows.

1) Two Variance Similarity Test (F-test)

Test the similarity of the two variances is done to determine the initial state of students by using a pretest. Pretest results to measure students' friendly character. The initial stage data analysis uses the two variance similarity test, that is the $\mathrm{F}$ count 1,98 and $\mathrm{F}$ table 2,37 . The results of $\mathrm{F}$ count $\angle \mathrm{F}$ table, so both groups have the same variance for the control group or experiment group so that parametric analysis can be calculated.

2) Normality Test and Homogeneity Test 
Normality and homogeneity tests were conducted to find out the experimental group and the control group with the same distribution. This data analysis is obtained from the value of the posttest to measure friendly characters. Recapitulation of the results of the normality and homogeneity test can be seen in Table 1 .

Table 1. Results of Normality Test and Homogeneity Test

\begin{tabular}{cccc}
\hline Test & $\begin{array}{c}\text { Source of } \\
\text { variation }\end{array}$ & $\begin{array}{c}\text { Friendly character } \\
\text { post-test control } \\
\text { group }\end{array}$ & $\begin{array}{c}\text { Friendly character } \\
\text { postest experiment } \\
\text { group }\end{array}$ \\
\hline Normality & $X^{2}$ count & 6,72 & 7,53 \\
& $X^{2}$ table & 9,49 & 9,49 \\
Homogeneity & Criteria & data is normally & distributed \\
& F count & 1,98 & data is normally \\
& F table & 2,37 & Both classes are \\
& & & homogeneous \\
\hline
\end{tabular}

Based on Table $\mathbf{1}$ it can be seen that the two groups are normally distributed and homogeneous.

3) The Two Average Difference Test (T-test)

This test is used to test the two average averages which can be seen in Table 2 below.

Table 2. Results of the Two Posttest Average Difference Tests

\begin{tabular}{ccc}
\hline Variation & \multicolumn{2}{c}{$\begin{array}{c}\text { Postest value of Friendly Character } \\
\text { control group }\end{array}$} \\
\hline Rata-rata & 82,97 & 29,39 \\
$\mathrm{dk}$ & 23 & 2,56 \\
$\mathrm{t}_{\text {count }}$ & 2,03 \\
$\mathrm{t}_{\text {table }}$ & The value of the friendly character of the experimental \\
Criteria & group students is the same as the character value of the \\
& \multicolumn{2}{c}{ control group students } \\
\hline
\end{tabular}

Table 2 shows the results that the difference test of two average posttest values of friendly characters in the control group averaged 82.97 while the experimental group with an average value of 89.39. The results of the analysis of $t$ count $>t$ table are $2.06>2.03$ so that the results of the values of the friendly character of the experiment group are the same as the character values of the control group

4) Gain Test

Table 3. Creative Character Gain Test Results

\begin{tabular}{ccccc}
\hline Average & Pre-test & Pos-test & Gain & Criteria \\
\hline eksperiment & 77 & 89 & 0,53 & medium \\
control & 77 & 83 & 0,25 & low \\
\hline
\end{tabular}


The result of increasing the value of friendly characters in the experimental group obtained a gain score of 0.53 with the medium criteria. Whereas in the control group obtained a gain score of 0.25 with low criteria. Friendly character gain can be seen in Figure 2 .

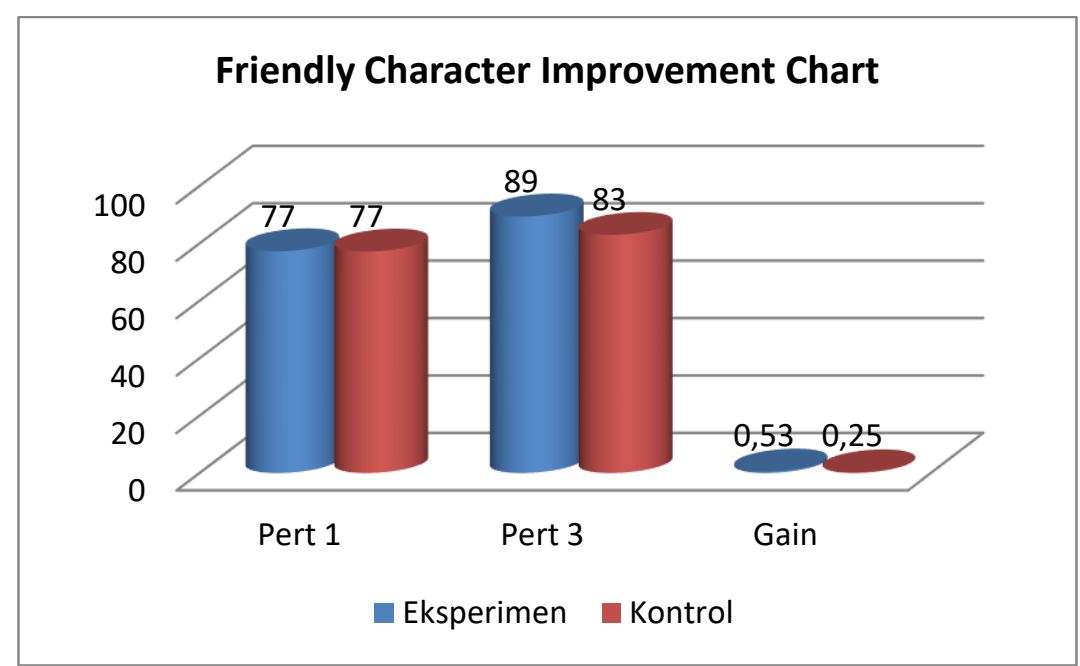

Figure 2. An improved character friendly diagram

Based on the results of data analysis, it can be explained that the indicators working together in groups achieve very good results because students show happiness and play more than one friend, all students can recognize that the success of the group because of the collaboration. Indicators speak politely show good results that students are able to speak politely without shouting friends while playing together. The indicator of playing without choosing a friend shows that there is an increase that students want to be a team with anyone when playing games. The thing that needs to be improved is that when playing there are still some students who impose their will, directly answering questions on the card after playing without discussing with their friends so that when the answer is wrong, the next friend cannot play. However, in general, based on the results of the analysis, it was obtained the results that the game crunch can increase the value of friendly characters in thematic learning.

The results of the presentation of the data above in the experimental group and the control group revealed that the friendly characters were shown to increase with the application of traditional engklek games in the 3rd grade of Muhammadiyah 1 Elementary School in Kudus Indonesia. Understanding how children engage in play and games is to understand their subculture and this could be a key to finding ways to educate children in terms of subjects taught at school[13]. This result has been seen since the implementation of the crunch game at the first meeting. The students seemed curious about the media provided, from the curiosity the students were interested and more eager to pay attention to learning. Arrives when instructions are given that students will learn outside the classroom by playing. All seemed enthusiastic and excited, this was because the teacher had never invited him to study with the car. In accordance with the instructions that have been conveyed the students start to do engklek games in groups.

When playing a game on engklek, students who have successfully performed a one-round game will take a question card to answer the quiz for those who successfully answer it will get points and may continue in the next round. Students look compact in playing the game until 
they become winners. They are able to understand the subject matter while playing. Not just cohesiveness but also physical and motor strength will also affect its success. This is in accordance with Through the game children can learn about themselves, others and their environment[2]. At the age of third-grade elementary school children are the most suitable period for developing physical motoric, cognitive, language, and social-emotional abilities.

Togetherness, cohesiveness, and collaboration between students in traditional games "engklek "is a form of friendly character. The interaction that occurs in students shows mutual intimacy and excitement when playing krlek. This proves that students are actually more able to create and explore while learning without being limited by the classroom. Because learning is not just a transformation of science but rather the learning process of how to make students comfortable and happy to learn, one of which is using traditional games in learning activities. Andriani argues that aspects of traditional games include: a) physical aspects consisting of strength and immune system, b) psychic aspects include the elements of thinking, counting, solving problems, and c) social aspects including cooperation, regularity, respect [2].

Character security will grow from habituation done by students to try to become later civilized people. This is consistent with the results of In-Jae Lee's research that "To develop a good character, a person has to try hard for his or her lifetime, and the circumstances he survives also have to be moral to contribute to his moral life. Schools can play a central role in the process of schools in modern society are poised to be the backbone in Character Education and thus need to propel it with apparent purpose, and effective strategies[14]. Friendly character values are applied to elementary school students from an early age so that they are accustomed to expressing their feelings and making students aware of the importance of living socializing and training them to be able to cooperate with anyone regardless of social, cultural and religious backgrounds [15].

\section{Conclusion}

Creative and innovative learning is not only equipped with modern technology tools, but more meaningful is to make students realize the importance of learning to love culture and diversity in Indonesia through experience. Who else will preserve the potential of local wisdom if not the next generation? Keep in mind now that many children have behaved less in accordance with the character of the nation, local culture has begun to wear off with the era of globalization. In this study, efforts have been made to improve the value of the nation's character, especially the friendly character through traditional games of engklek in thematic learning in grade 3 of Muhammadiyah 1 Kudus.

The results of the research on the use of engklek games can improve the value of the health of grade 3 students in thematic learning at Muhammadiyah 1 Elementary School. Experimental control group pre-test post-test study that has been conducted that traditional games can improve friendship. Improvement of the friendly character of the experimental group increased significantly from the pretest score 77 post-tests to 89 , the result of the gain test was 0.53 with the criteria being medium. While the experimental group obtained pretest score 77 post-tests to 83 with the results of the gain test 0.25 low criteria. The value of friendly characters increases in the indicators of working together in groups, speaking politely, playing without choosing friends and paying attention to friends talking in thematic learning using the engklek games. 


\section{References}

[1] Kementrian Pendidikan Nasional Badan Penelitian Pengembangan Pusat Kurikulum, Bahan Pelatihan: Pengembangan Pendidikan Budaya dan Karakter Bangsa. Jakarta: Kemendiknas, 2010.

[2] T. Andriani, "Permianan Tradisional dalam Membentuk Karakter Anak Usia Dini," J. Seni Budaya, vol. 9, no. 1, pp. 121-136, 2012.

[3] Ika Ari Pratiwi, "Pendidikan Multikutural untuk Menanamkan Karakter Bangsa Bagi Siswa Sekolah Dasar," in Telecon: Teaching, Linguistics, culture and educational conference, 2016.

[4] Zainuddin, "Implementasi Pembentukan Karakter Bersahabat Melalui Model Pembelajaran Group Investigasi," Mimbar, vol. 29, no. 1, pp. 69-79, 2013.

[5] Sukirman, Permainan Tradisional Jawa. Yogyakarta: Kepel Press, 2004.

[6] Sri Mulyani, 45 Permainan Tradisional Anak Indonesia. Yogyakarta: Langensari Publishing, 2013.

[7] Wardani, Permainan Tradisional yang Mendidik. Yogyakarta: Cakrawala, 2010.

[8] Iris Soute, Panos Markopoulos, and Remco Magielse, "Head Up Games: Combining the best of Both Worlds by Merging Traditional and Digital Play," Pers Ubiquit Comput, vol. 14, no. 5, pp. 435-444, 2010.

[9] R. Badu, "Pengembangan model Pelatihan Permainan Tradisional Edukatif Berbasis Potensi Lokal Dalam Meningkatkan kemampuan dan Keterampilan Orang Tua Anak Usia Dini di Paud Kota Gorontalo," J. Penelit. dan Pendidik., vol. 8, no. 1, pp. 70-77, 2011.

[10] D. Apriani, "Penerapan Permainan Tradisional Engklek untuk Meningkatkan Kemampuan Motorik Kasar Anak Kelompok B RA Al-Hidayah 2 Tarik Sidoarjo," PAUD Teratai, vol. 2, no. 1, 2013.

[11] H. Nur, "Membangun Karakter Anak Melalui Permainan Anak Tradisional," J. Pendidik. Karakter, vol. III, no. 1, pp. 87-94, 2013.

[12] Sugiyono, Penelitian Kualitatif, Kuantitatif dan R\&D. Bandung: Alfabeta, 2009.

[13] J. R. Chepyator-Thomson, "Traditional Games of Keiyo Children: A Comparison of Pre- and Post-Independent Periods in Kenya," Interghange, vol. 21, no. 2, pp. 15-25, 1990.

[14] In-Jae Lee, "The Proper Directions and Practical Ways for Character Education in the Korean Elementary school," Asia Pacific Educ. Rev., vol. 2, no. 2, pp. 72-84, 2001.

[15] Ika Ari Pratiwi, S. Masfuah, and W. S. Rondli, "Pendidikan Multikultual Berbantuan Metode Pictorial Riddle untuk Meningkatkan Karakter Kreatif dan Bersahabat Siswa Kelas 3 Sekolah Dasar," Sch. J. Pendidik. dan Kebud., vol. 8, no. 2, pp. 109-119, 2018. 